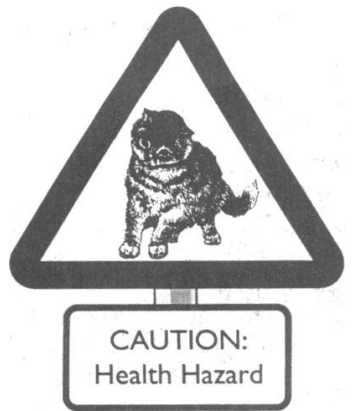

tonitis. Culture of the line grew Staphylococcus homini sensitive to vancomycin. The fluid was sterile.

Case 3-A 73 year old man had fluid indwell when his cat punctured the dialysis line with its claws. $\mathrm{He}$ was given vancomycin and had no further problems. The fluid was sterile.

Case 4-A 24 year old woman had her dialysis line bitten by her kitten while she was asleep with fluid indwell. She was given vancomycin and was started on oral ciprofloxacin. She remained free of symptoms; the fluid was sterile.

\section{Comment}

The nature of continuous ambulatory peritoneal dialysis, with a patient using four exchanges a day and having to break the closed system 1500 times per year, means that peritonitis is a common problem-it has an incidence of 1.5 episodes per patient per year. ${ }^{1}$ The most common source of infection is the patient's own skin flora, Staphylococcus epidermis, accounting for $53 \%$ of culture positive episodes. ${ }^{1}$ Antistaphylococcal drugs are therefore given as soon as possible after an accidental breach of the closed system.

We are not aware of previous reports of pets causing peritonitis by puncturing the closed system, but poor hygiene after disposal of poodle faeces has been reported to have resulted in peritonitis. ${ }^{2}$ Of the 10 line breaks in our CAPD programme in two years, four have been caused by cats.

A further problem when animals are involved, which is highlighted in our first case, is that the resulting peritonitis may be caused by an organism not sensitive to firstline antibiotics. Peritonitis from Neisseria species without animal interference has been described, ${ }^{34}$ but it is rare and probably results from haematogenous spread from the patient's oropharynx. ${ }^{4}$ Neisseria species have been isolated from the supragingival plaque of domestic cats. ${ }^{5}$ This suggests that the peritonitis in our first case resulted from direct inoculation of the organism into the fluid as it was running into the abdomen.

We conclude that cats are a significant hazard for patients receiving continuous ambulatory peritoneal dialysis, and we recommend some precautions for patients with a cat. The animal must not be in the same room when the patient is performing a fluid exchange; the animal must not sleep in the bedroom with the patient at night; dialysis fluid must be stored away from pets. Finally, interference by a cat may result in an infection with an unusual organism and treatment should be adjusted accordingly.

1 Heaton A, Rodger RSC, Sellars L, Goodship THJ, Fletcher R, Nikolakakis N $a l$. Continuous ambulatory peritoneal dialysis after the honeymoon: review of experience in Newcastle 1979-84. BMF 1986;293:938-41.

2 Fannelli C, Peterson CJ, Schoolworth AC. Poodle peritonitis. Peritoneal Dialysis International 1990;10:247-8.

3 Dadone C, Vigano F, Mariani P, Giltri C. Peritonitis caused by Neisseria species in CAPD. Peritoneal Dialysis Bulletin 1985;5:138.

4 Damani NN, Chin ATL, Branhamella catarrhalis peritonitis in a continuous ambulatory peritoneal dialysis patient. Nephron 1987;45:160-1.

5 Dent VE. Identification of oral Neisseria species of animals. 3 Appl Bacterio 1982;52:21-30.

\title{
A potpourri of parasites in poetry and proverb
}

\section{A Burns}

Ectoparasites, you may consider, hardly provide suitable material for flights of poetic fancy, but it is surprising how many verses have been composed with fleas, lice, and scabies as the main subject matter. Many of these express sentiments inclined towards affection for these cutaneous passengers, and a few even mention parasites in an amorous setting. I have not been able to discover any poetic works of note relating to the crab louse, most of the references to this louse having been committed to the walls of public conveniences by contemplative graffiti artists, and thereby eventually lost to scrutiny under successive layers of emulsion paint. It is a pity that this much maligned louse has not, as far as I am aware, attracted the attention of a poet whose creativity stretches beyond "There was a young lady from Hitchin...."

\section{Scabies mites}

As we all know, scabies is transmitted by close physical contact, and not by contact with fomites. But it was not until the work of Mellanby that the necessity for close physical contact in the spread of scabies was appreciated..$^{12} \mathrm{He}$ conducted a number of experiments using volunteers in the early 1940s and established that clothing and bedding were not important in the spread of scabies. He also realised that there is a latent period of about four weeks after infection is acquired before itching begins. His volunteers were a group of conscientious objectors, and the research establishment was a house in the Sheffield suburb of Broomhill. The group produced its own coat of arms-bearing the motto "Itch dien."

At one stage in Mellanby's investigations the findings of his research were included in a play in verse about scabies and its social implications. The play was produced at a Christmas party and contained this offering:

Recondite research on Sarcoptes

Has revealed that infections begin

At home with your wives and your children

Or when you are living in sin.

Except in the case of the clergy

Who accomplish remarkable feats

And catch scabies and crabs

From doorhandles and cabs

And from blankets and lavatory seats.

Scabies mites burrow in the epidermis, and this activity is celebrated in one stanza of a delightful poem originating from Guy's Hospital:

There's a squeak of pure delight from a matey little mite,

As it tortuously tunnels in the skin.

Singing furrow, Folly furrow, come and join me in my burrow,

And we'll view the epidermis from within. ${ }^{3}$

Many remedies for scabies have been suggested, but for centuries the standard treatment was with sulphur. In fact, sulphur ointment is still used by some dermatologists. Rotenone, an extract of derris root, was used in the 1940s to treat scabies. Although it was effective, it was rather irritant, particularly to the delicate body parts of the male. In 1937 Kissmeyer introduced benzyl benzoate as a scabicide, and it has remained in use ever since. These three therapeutic agents are celebrated in this offering from the 1940s:

The treatment most in vogue of late

Concerns the benzyl benzoate,

Made up in water it's applied

All over every patient's hide.

It cures a very high proportion

When used with care and skill and caution. 
Derris root yields rotenone

Which some say will cure alone

Without a bath or scrub or soap

(This surely is the soldier's hope)

This treatment seldom has a failure

But woe betide the genitalia.

But if you must be safe and sure,

Use the good old-fashioned cure.

Cover the victim with soft soap

Then in hot water let him soak,

A scrubbing next is his appointment

And finish off with sulphur ointment!

\section{Head lice}

The concept that head lice colonise only dirty scalps, and that dirty scalps are the sole prerogative of the proletariat, is deeply ingrained in the lore of this insect. Anyone may acquire head lice, whether they wash their hair once a day or once a year-though the lice of the former will be more presentable than those of the latter. In England in the 1940s head louse infection was extremely common but occurred predominantly in the lower classes in industrial conurbations, there being little or no problem in rural areas and in upper social echelons. Although the incidence of infection gradually declined, this distribution pattern persisted until the early 1980 s, when head lice became quite common in suburban and rural areas, particularly among the bourgeoisie: the head louse had joined the class struggle.

Robert Burns obviously had definite ideas about the proper place for a head louse when he advised one to move from a lady's bonnet to an environment more appropriate to its social standing:

To a Louse, on seeing one on a Lady's Bonnet, in Church

Ye ugle, creepin, blastit wonner,

Detested, shunned by saunt an' sinner.

How dare ye set your fit upon her, Sae fine a lady.

Gae somewhere else and seek your dinner On some poor body. ${ }^{4}$

It is known that head lice frequent the coiffure of females of all ages more often than they do the male tonsure. This, perhaps with an additional hint of male chauvinism, may have coloured an offering from Henry Fox, after he had been offended by Lady Montague:

Lady Montague told me and in her own house,

"I do not care for you three skips of a louse."

I forgive her, for women, however well-bred,

Will still talk of that which runs most in their head. ${ }^{5}$

\section{Body lice}

In developed countries body lice are usually encountered only on vagabonds and "down and outs." This is the louse of abject poverty, and establishes itself on those who rarely wash and almost never remove their clothes. This louse should preferably be referred to as the clothing louse, as its habitat is the clothing of its host. It prefers an environment with a constant temperature; hence its affinity for those whose clothing is permanently in situ. It is sensitive to temperature changes and tends to move away from a feverish host and one recently deceased. The morning after archbishop Thomas Becket's murder in Canterbury Cathedral (29 December 1170), when multiple layers of clothing were being removed from his body, the haircloth garment close to the skin "boiled over with [lice] like water in a simmering cauldron."

A poem by Gordon Bottomley (1874-1948) graphically describes the departure of a louse from the corpse of a lady. Her body is no longer attractive to it, and the louse does not relish the thought of being eaten by worms:

A louse crept out of my lady's shift-

Ahumm, Ahumm, Ahee-

Crying "Oi! Oi! We are turned adrift;

The lady's bosom is cold and stiffed,

And her arm-pit's cold for me."

“The lady's linen's no longer neat"Ahumm, Ahumm, Ahee-

"Her savour is neither warm nor sweet;

It's close for two in a winding sheet,

And lice are too good for worms to eat;

So here's no place for me."

The louse made off unhappy and wetAhumm, Ahumm, Ahee-

He's looking for us, the little pet;

So haste, for her chin's to tie up yet,

And let us be gone with what we can get-

Her ring for thee, her gown for Bet,

Her pocket turned out for me. ${ }^{6}$

The unsavoury nature of lice has also spawned numerous proverbs, many reflecting its lack of appeal (box).

\section{The proverbial louse}

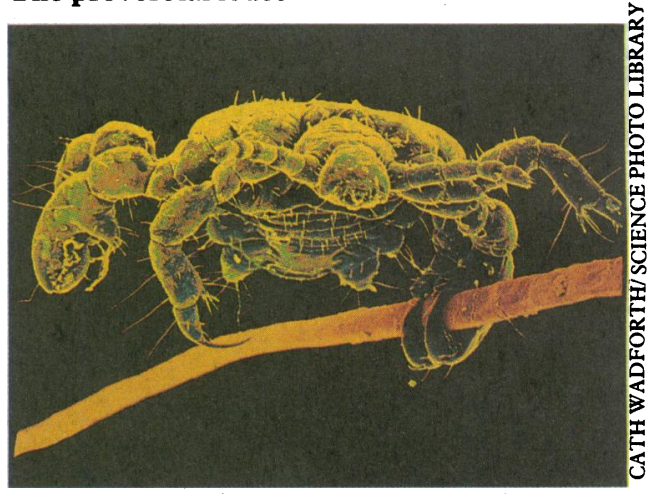

Nits will be lice.

Sue a beggar and get a louse.

A begger pays a benefit with a louse.

Nothing so crouse [brisk] as a new washen louse.

A rogue's wardrobe is harbour for a louse.

As sure [safe] as a louse in Pomfret.

As sure [safe] as a louse in bosom.

Better a louse in the pot than no flesh at all.

\section{Crab lice}

As mentioned previously, the crab louse, because of its association with the nether regions, has inspired poets lavatorial to exercise their creative talents in N graffiti. Crab lice are transmitted by close physical N contact, usually close encounters of a sexual kind, and ${ }_{\sigma}^{\omega}$ hinged lavatory components are unlikely to play any part in their spread. However, paranoia about public? toilets is encouraged by the following jingle:

It's no good standing on the seat,

The crabs in here can jump ten feet.

Underneath which is usually inscribed:

If you think that's rather high,

Go next door, the buggers fly.

And there are limericks to be found among thi reading matter-

A sultan named Abou ben Adhem,

Thus cautioned a travelling madam,

"I suffer from crabs

As do most us A-rabs."

"It's all right," said the madam, "I've had 'em." 


\section{The proverbial flea}

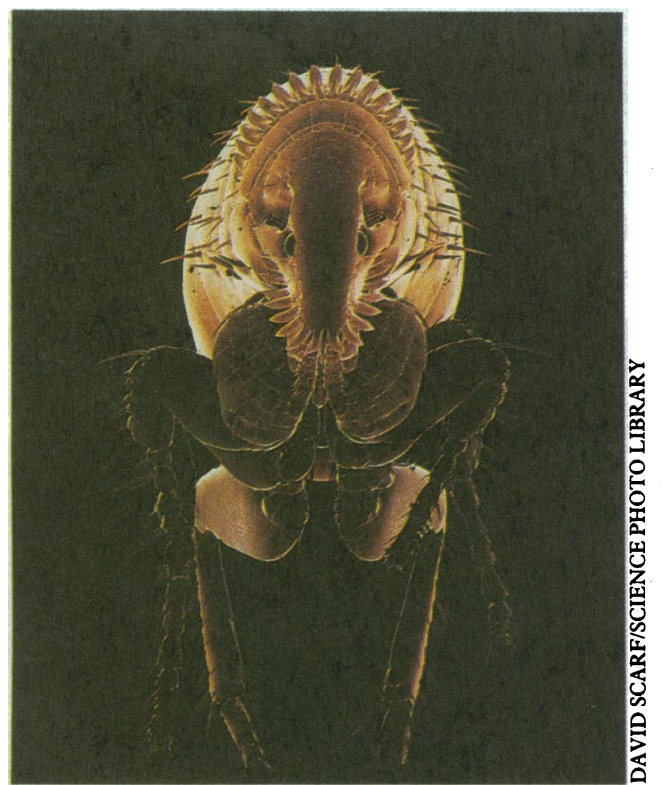

The dog that is idle barks at his fleas, but he that is hunting feels them not. (Chinese proverb)

He that lies with the dogs, riseth with fleas.

Nothing must be done hastily but killing of fleas.

If you kill one flea in March, you kill a hundred.

An Englishman will burn a bed to catch a flea. (Turkish proverb)

-including that young lady from Hitchin

There was a young lady from Hitchin,

Who was scratching her groin in the kitchen.

Her mother said "Rose,

"It's the crabs I suppose."

She said "Yes, and the buggers are itchin'."

\section{Fleas}

The human flea, Pulex irritans, is now resident in England only on pigs. Our household flea infestations nowadays are produced by fleas derived from our domestic pets. They feed on the animal, but infest our houses, developing in the carpets and in the pets' bedding, becoming particularly abundant towards the end of hot, humid summers. When dealing with domestic cat or dog flea infestation, efforts should be directed at the house as well as the animal. Proprietary flea sprays for carpets and soft furnishings should be used regularly to keep the flea population at bay.

In the past, when human fleas were common, a certain grudging acceptance of them seems to have been acquired, and indeed the flea has perhaps attracted more attention from poets than any other insect. ${ }^{4}$ Songs have also been written about fleas-for example, "The Song of the Flea" by Mussorgsky. There is even an opera devoted to a flea with the Midas touch: "La pulce d'oro" by Ghedini.

The first line of the following poem by the Victorian mathematician Augustus de Morgan is well known:

Great fleas have little fleas upon their backs to bite 'em And little fleas have lesser fleas, and so ad infinitum.

And the great fleas themselves, in turn, have greater fleas to go on;

While these in turn have greater still, and greater still, and so on. ${ }^{5}$

And there is the offering from Dean Swift:

So Nat'ralists observe, a flea

Hath smaller fleas that on him prey;

And these have smaller fleas to bite 'em,

And so proceed ad infinitum. ${ }^{7}$
And an abbreviated version from $R$ R Fielder:

Big fleas have little fleas to plague, perplex and bite 'em,

Little fleas have lesser fleas, and so ad infinitum.

John Donne may be the only poet who has written about the flea in an amorous setting, and this abstract from his poem "The Flea" elevates the feeding habits of this insect to a romantic plane:

Marke but this flea, and marke in this,

How little that which thou deny'st me is;

It suck'd me first, and now sucks thee,

And in this flea, our two bloods mingled bee;

Thou know'st that this cannot be said

A sinne, nor shame, nor losse of maidenhead,

Yet this enjoyes before it wooe,

And pamper'd swells with one blood made of two,

And this, alas, is more than wee would doe. ${ }^{8}$

The conjugal activities of fleas and their powers of replication have also attracted some attention:

The male and female flea to you

Do not appear distinct;

But fleas can tell which one is who

When maritally linked. ${ }^{9}$

An odd little thing is the flea

You can't tell a he from a she

But he can, and she can-

Whoopee! $!^{10}$

The arithmetic flea

Adds to your misery

Subtracts your pleasure

Divides your attention

And multiplies like the devil.

Spike Milligan suggests a method of prophylaxis against flea bites:

Lady Barnaby takes her ease

Knitting overcoats for fleas.

By this kindness fleas are smitten,

That's why she's very rarely bitten. ${ }^{11}$

Thomas Tusser, the Elizabethan agriculturalist, has another remedy:

While wormwood hath seed, get a handful or twaine,

To save against March, to make flea to refraine.

Where chamber is sweeped, and wormwood is strown,

No flea for his life dare abide to be known.

Fleas are also a rich source of proverbs, of which the box shows a selection.

\section{Bed bugs}

Finally, the poor old bed bug - not a very attractive insect. Hiding behind peeling wallpaper and rotten skirting boards, and in old mattresses and bed-frames, it emerges an hour or so before dawn to feed on the

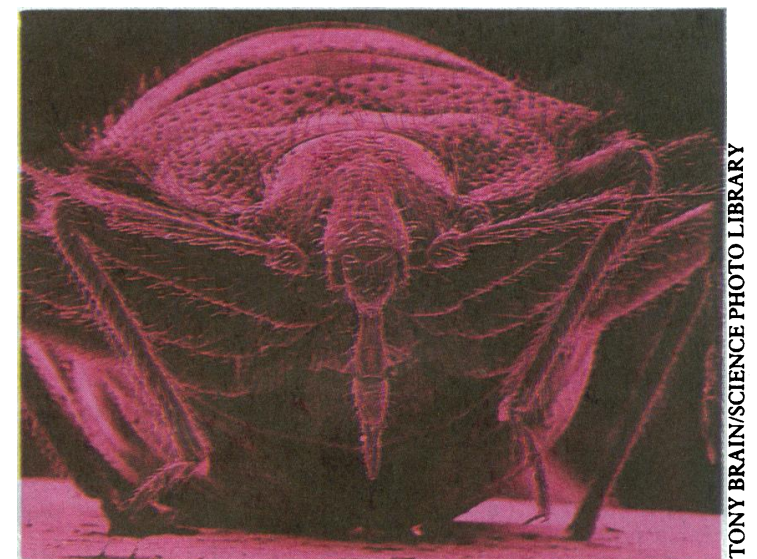

Last but not least-the bed bug, "not a very attractive insect." All photographs are false colour scanning electron micrographs 
sleeping occupants of the bedroom. Its capacity to resist starvation is legendary, but it has few other outstanding qualities (apart from one of the most peculiar methods of copulation in the insect world)... but I digress. Someone at least appreciated its dogged determination to seek out its host when writing the following:

The butterfly has wings of gold,

The firefly wings of flame;

The bed bug has no wings at all,

But he gets there just the same. ${ }^{12}$

1 Mellanby K. The transmission of scabies. $B M \mathcal{F} 1941$;ii:405-6.

2 Mellanby K. Human guinea pigs. London: Gollancz, 1945.
3 P R M Guy's acarus. Transactions of the St Fohn's Hospital Dermatological Society 1972;58:113.

4 Kingsley J, ed. The poems and songs of Robert Burns. Vol 1. Oxford: Clarendon, 1968:193-4.

5 Stevenson B. Stevenson's book of quotations. 10th ed. London: Cassell, 1967: $1171,679$.

6 Bottomley G. The elder woman's songs. From "King Lear's Wife." In: Poems of thirty years. London: Constable, 1925:106.

7 Swift J. On poetry: a rapsody. In: Davis H, ed. Swift: poetical works. London: Oxford University Press, 1967:578.

8 Donne J. The Flea. In: Hayward J, ed. Fohn Donne: poetry. London: Penguin, 1986:48.

9 Lehane B. The compleat flea. London: John Murray, 1969:94, 37, 30

10 Flighty fleas. In: Silcock A. Verse and worse. London: Faber and Faber, 1969:242.

11 Milligan S. Lady B's Fleas. In: Patten B, ed. The Puffin book of twentiethcentury children's verse. London: Penguin, 1991:162.

12 The terror by night. In: Shrewsbury JFD. The plague of the Philistines. London: Gollancz, 1964:146.

\section{Modifying chickenpox}

\section{Eric Pennington, Sheila Pennington}

It is commonly accepted folklore in general practice that a patient with chickenpox, kept cool, has less itching. Nevertheless, skin temperature has never been shown to have any objective effect on the severity of the illness in children. In most people the typical distribution of the rash coincides with the part of the body that is usually the warmest: the head, trunk, and proximal limbs. Theoretical consideration might suggest, therefore, that the number of spots in chickenpox is related to skin temperature. Chickenpox occurs in sporadic outbreaks, usually in small children, so it is difficult to design a controlled experiment to assess this theory. Our report shows, in a single individual, that cutaneous temperature affects the severity of chickenpox.

\section{Method and results}

On diagnosis of chickenpox a garment was constructed consisting of a woollen jumper with one arm pulled through the other, forming a double thickness half jumper. This was sewn to a long sleeved shirt (figure). Thus the right half of the torso had two layers of jumper plus a shirt and the left had only a shirt. A similar pyjama top was constructed. The patient accepted these garments and wore them throughout the experiment.

The attack of chickenpox was mild, and spots erupted over only two days. The number of spots on each side of the midline of the area covered by the trial garment was counted at the end of each day. On the first day there were 11 spots on the left (cool) side and 27 on the right (warm) side. On the second and third days the numbers were 20 and 34, and on the fourth day there were 18 spots on the cool side and 34 on the warm side.

The results confirm, in a single subject, our clinical impression that reducing cutaneous temperature reduces the number of spots in cases of chickenpox.

\section{Moseley, Birmingham B13.9YD \\ Eric Pennington, DRCOG, general practitioner Sheila Pennington, DRCOG, general practitioner}

\section{Correspondence to:}

Dr E Pennington.

$B M \mathcal{F}$ 1991;303:1614

\section{Comment}

We noticed several years ago that children with chickenpox whose homes were kept at a high temperature, or who were wrapped up warm when ill, seemed to have more spots. This prospective study confirms our suspicion that it is possible to modify the course of chickenpox simply by controlling cutaneous temperature. A chance observation provides a possible mechanism for this finding. Chickenpox occurred in a patient while a laparotomy wound was healing and a Koebner phenomenon was noted of clustering of

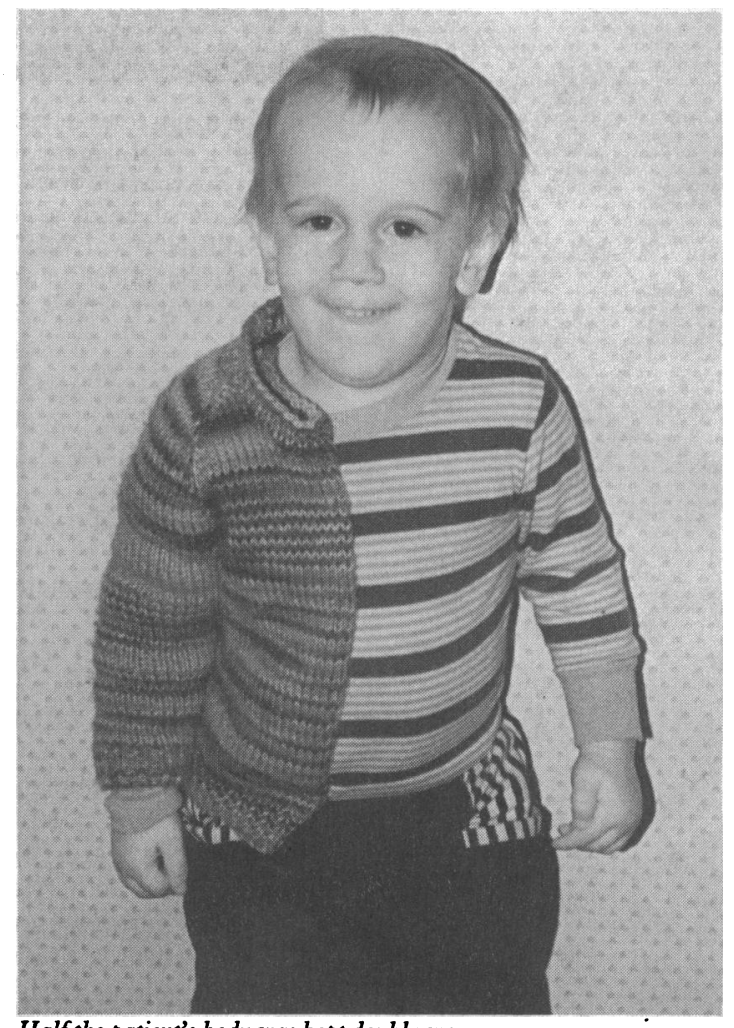

Half the patient's body was kept doubly warm

the chickenpox around the incision area. Increased cutaneous blood flow and raised skin temperature are common to both observations.'

One serious implication of this study is for research on the efficacy of antiviral agents against chickenpox. These studies comparing a drug against placebo often quote the extent of the rash as one index of severity. They may need to include skin temperature as a variable if meaningful results are to be obtained. Recent studies do not seem to have done so. ${ }^{2-4}$

Skin temperature seems to have a major influence on the severity of rash in chickenpox. This can be reduced by light clothing and turning down the central heating.

1 Healsmith MF, Berth-Jones J, Graham-Brown RAC. Koebner phenomenon in varicella. $B M \mathcal{F}$ 1990;301:1286.

2 Balfour HH, Kelly JM, Suares CS, Heusser RC, Englund JA, Crane DD, et al. Acyclovir treatment of varicella in otherwise healthy children. $\mathcal{J}$ Pediatr 1990;116:633-9.

3 Boyd E, Walker E. Use of acyclovir to treat chickenpox in pregnancy. $B M \mathcal{J}$ 1988;296:393-4.

4 Peterslund NA. Management of varicella zoster infections in immunocompeten hosts. Am f Med 1988;85(suppl 2a):74-8. 